\title{
UPAYA MENINGKATKAN PERCAYA DIRI MELALUI BIMBINGAN KELOMPOK TEKNIK PERMAINAN PADA SISWA KELAS XI IPA-1 MATA PELAJARAN BK SEMESTER GENAP SMA NEGERI 1 PINANGSORI TAHUN PELAJARAN $2016 / 2017$
}

\author{
Mina Taraja, S.Pd \\ Guru SMA Negeri 1 Pinangsori Kabupaten Tapanuli Tengah
}

\begin{abstract}
Abstrak
Penelitian ini bertujuan untuk mengetahui kondisi siswa sebelum dan sesudah dilakukan layanan bimbingan kelompok teknik permainan. serta untuk mengetahui besar prosentase siswa yang memiliki percaya diri sesudah dilakukan layanan bimbingan kelompok. Setelah tindakan fakta siklus I, peneliti memberikan kuesioner tentang percaya diri untuk selanjutnya dianalisis dan hasilnya didokumentasikan. Demikian pula pada siklus II. Hasil penelitian menunjukkan bahwa pada kondisi awal siswa yang memiliki percaya diri hanya sebesar 38\% maka dilakukan tindakan siklus I dan siklus II untuk meningkatkan jumlah siswa yang memiliki percaya diri. Ketika mengikuti kegiatan layanan bimbingan, keaktifan dan antusias siswa dari berbagai aspek meningkat dari kegiatan pertama 20\% menjadi 24\% pada kegiatan kedua, dan meningkat lagi menjadi $36 \%$ pada kegiatan ketiga siklus I. Kemudian ada peningkatan pada kegiatan satu siklus II yaitu menjadi 56\% kemudian meningkat lagi menjadi 88\% pada kegiatan dan siklus II. Dari hasil kuesioner percaya diri setelah siklus I siswa yang mendapat nilai positif maupun sangat positif 59\%, pada siklus II menjadi 82\%. Melihat kenyataan tersebut dapat disimpulkan bahwa layanan bimbingan kelompok dapat meningkatkan percaya diri pada siswa kelas XI IPA 1 SMA Negeri 1 Pinangsori.
\end{abstract}

Kata kunci: percaya diri, layanan bimbingan kelompok teknik permainan

\section{Pendahuluan}

Perkembangan anak merupakan proses yang komplek, terbcntuk dari potensi diri anak yang bersangkutan dan lingkungan sekitarnya yaitu keluarga, sekolah, dan lingkungan masyarakat. Artinya ada beberapa perkembangan yang dipengaruhi oleh faktor bawaan dan ada beberapa perkembangan yang dipengaruhi oleh lingkungan pertama dan utama yang berpengaruh terhadap perkembangan anak adalah lingkungan keluarga dimana orang tua yang menaruh harapan sosok yang paling berperan. Menurut Bandura (1997: 21), keyakinan akan kemampuan diri sendiri untuk menguasai situasi dan menyelesaikan tugas-tugas yang dianggap sulit disebut self 
efficacy. Self efficacy mempengaruhi usaha individu, seberapa besar individu memiliki daya tahan meughadapi kesulitan dan reaksi emosi yang ditujukan pada saat menghadapi tugas. Pada kenyataan yang ada siswa klas X1 IPA-1 sesuai laporan dari para guru yang mengajar maupun dari hasil pengamatan pada saat mengikuti kegiatan bimbingan ternyata masih ada siswa yang menunjukkan kurang percaya diri, banyak diam ketika menerima pelajaran/bimbingan, tidak berani mengemukakan pendapat, merasa dirinya kurang, bahkan pasif dalam mengikuti berbagai kegiatan.

\section{Percaya Diri (Setf Confidence)} adalah meyakinkan pada kemampuan dan Penilaian (judgement) diri sendiri dalam melakukan tugas dan memilih pendekatan yang efektif Hal ini termasuk kepercayaan atas kemampuannya menghadapi lingkungan yang semakin menantang dan kepercayaan atas keputusan atau pendapatnya. Orang yang tidak percaya diri akan merasa terus menerus jatuh, takut untuk mencoba, merasa ada yang salah dan khawatir (Elly Risman, 2003: 151).

Rusaknya kepercayaan diri tidak dapat tumbuh dalam satu hari. Lingkungan banyak punya andil membentuknya. Elly Risman mengibaratkan jiwa manusia sebagai kendi tabungan tua, kakek, nenek, teman, guru, tetangga adalah orang- orang disekitar, yang mengisi atau bahkan menguras kendi itu.

Para ahli berkeyakinan bahwa kepercayaan diri bukanlah diperoleh secara instant, melainkan melalui proses yang berlangsung sejak usia dini dalam kehidupan bersama orangtua Meskipun banyak faktor yang mempengaruhi kepercayaan diri seseorang, namun faktor pola asuh dan interaksi di usia dini merupakan faktor yang am at mendasar bagi pembentukan rasa percaya diri. Sikap orangtua akan diterima oleh anak sesuai dengan persepsinya pada saat itu. Orangtua yang menunjukkan perhatian, penerimaan, cinta dan kasih sayang serta kelekatan emosional yang tulus dengan anak akan membangkitkan rasa percaya diri pada anak terse but. Anak akan merasa bahwa dirinya berharga dan bernilai di mata orangtuanya Dan meskipun ia melakukan kesalahan, dari sikap orangtua anak melihat bahwa dirinya tetaplah dihargai dan dikasihi Anak dicintai dan dihargai bukan tergantung pada prestasi atau perbuatan baiknya, namun karena eksistensinya. Di kemudian hari anak tersebut akan tumbuh menjadi individu yang mampu menilai positif dirinya dan mempunyai harapan yang realistik terhadap diri seperti orangtuanya meletakkan harapan realistik terhadap dirinya.

Berdasarkan kenyataan tersebut diatas, maka untuk membantu penyelesaian masalah yang dialami siswa dan upaya memperbaiki kinerja khususnya menyangkut metode penyelenggaraan layanan bimbingan konseling agar penyelenggaraan layanan bimbingan konseling dapat mencapai tujuannya secara maksimal, salah satu metode yang akan dilakukan adalah bimbingan kelompok teknik permainan potret diri. Karena melalui layanan bimbingan kelompok topik bimbingan yang disampaikan mudah dipahami. Dengan pengalaman langsung siswa dapat 
mengkaitkan pemahaman perilaku melalui kelompok, dengan layanan bimbingan kelompok siswa menjadi peka akan perilaku yang dilakukan.

Dalam hidup bermasyarakat, setiap individu mengalami berbagai masalah, kejadian, bertemu orang-orang baru, dan sebagainya. Reaksi individu terhadap seseorang atau pun sebuah peristiwa sangat dipengaruhi oleh cara berpikirnya. Dengan rasa percaya diri yang lemah cenderung mempersepsikan segala sesuatu dari sisi negatif.

Berdasarkan latar belakang masalah maka permasalahan penelitian ini dapat dirumuskan sebagai berikut:

1. Bagaimana kondisi siswa sebelum dilakukan layanan bimbingan kelompok teknik permainan?

2. Bagaimana kondisi siswa sesudah dilakukan layanan bimbingan kelompok teknik permainan?

3. Berapa besar prosentase siswa yang memiliki percaya diri sesudah dilakukan layanan bimbingan kelompok teknik permainan?

\section{Metode Penelitian}

Penelitian ini akan dilaksanakan di SMA Negeri 1 Pinangsori dari bulan Januari minggu ke-1 sampai dengan bulan April minggu ke-1 tahun 2017. Kegiatan penelitian ini diimplementasikan oleh satu orang peneliti (guru Bimbingan Konseling dibantu 1 orang teman sejawat sebagai observer). Kelas yang digunakan dalam penelitian ini adalah kelas XI IPA-1 dengan jumlah 36 siswa. Sedangkan jumlah siswa yang diteliti sebanyak 12 siswa. Penelitian ini dilaksanakan 2 siklus, setiap siklus terdiri dari 3 kegiatan bimbingan kelompok, setiap kegiatan dilaksanakan observasi dan refleksi serta dilengkapi satuan layanan bimbingan kelompok.(satuan layanan awal dan satuan layanan perbaikan).

\section{Pembahasan dan Hasil}

Kondisi awal kelas X1 IPA 1 SMA Negeri 1 Pinangsori sebelum dilakukan kegiatan layanan bimbingan kelompok teknik permainan potret diri diperoleh dari laporan para guru yang mengajar maupun dari hasil pengamatan pada saat mengikuti kegiatan bimbingan dimana masih ada siswa yang menunjukkan kurang percaya diri, banyak diam ketika menerima pelajaran/bimbingan, tidak berani mengemukakan pendapat, merasa dirinya kurang, bahkan pasif dalam mengikuti berbagai kegiatan, keadaan itu diperoleh dari hasil pengisian Daftar Cek Masalah (DCM).

Hasil kuesioner menunjukkan bahwa besar prosentase siswa yang memiliki percaya diri sesudah dilakukan layanan bimbingan kelompok teknik permainan yaitu sebesar $82 \%$. Hal ini telah melebihi target yang ditetapkan yaitu sebesar $80 \%$ dari siswa mendapat nilai positif $80 \%$ sangat positif sehingga pelaksanaan siklus II tidak memerlukan kegiatan lanjutan.

\section{Kesimpulan}

Berdasarkan hasil penelitian dan pembahasan dapat disimpulkan bahwa melalui layanan bimbingan teknik 
permainan potret diri dapat meningkatkan rasa percaya diri pada siswa kelas X1 IPA SMA Negeri 1 Pinangsori. Hal ini dapat dilihat dari setiap kegiatan bimbingan kelompok keaktifan siswa serta kegairahan siswa meningkat dari berbagai aspek yang ditentukan, prosentase siswa yang aktif dan antusias pada kegiatan satu sebesar 20\% menjadi $24 \%$ pada kegiatan 2. Kemudian meningkat lagi menjadi $36 \%$ pada kegiatan tiga siklus I. Serta pada siklus dua kegiatan satu siswa yang .aktif dan antusias menjadi $56 \%$ dan pada kegiatan dua naik $88 \%$ sehingga memenuhi target bahkan melebihi target yang diharapkan yaitu sebesar $80 \%$.

Dilihat dari hasil kuesioner siswa tentang percaya diri sebelum diadakan tindakan bimbingan nilai positif dan sangat positif $38 \%$, setelab pelaksanaan siklus I, siswa yang mendapat nilai positif maupun siswa yang mendiapat nilai sangat positif mencapai 59\% sehingga menunjukkan peningkatan pada basil kuesioner tentang percaya diri setelah pelaksanaan siklus dua, siswa yang mendapat nilai positif maupun sangat positif menjadi $82 \%$. Hal ini menunjukkan bahwa target yang diharapkan telah tercapai.

\section{Saran}

Berdasarkan hasil penelitian, maka peneliti mengemukakan saran-saran sebagai berikut:

1) Diharapkan kepada guru BK untuk selalu meningkatan kemampuannya dalam memberikan layanan bimbingan kclompok kepada siswa.

2) Layanan bimbingan kelompok sangat efektif karena siswa langsung mendapatkan pengalaman untuk pemahaman perilaku yang baik dalam meningkatkan rasa percaya diri. Oleh karena itu, guru BK diharapkan memlliki kemampuan profesional yang mantap agar siswa tertarik untuk. mengikuti kegiatan layanan bimbingan kelompok sehingga siswa berhasil dalam meraih cita-citanya.

\section{Daftar Pustaka}

Anwar, Sutoyo. 2012. Pemahaman Individu Observasi, Checklist, Interview, Kuesioner, Sosiometri: Yogyakarta Pustaka Pelajar.

Modul Pusat Pengembangan dan Pemberdayaan Pendidik dan Tenaga Pendidikan Jasmani dan Bimbingan Konseling.

Nurihsan Achmad Juntika. 2005. Strategi Layanan Bimbingan \& Konseling. Bandung: Refika Adi tama.

Risman Elly.(2003).

Http://digilib.Sunan-ampel.ac.id/flles / disk $1 / 198$ /fibtiain :

citamariau - 9858 - 5 babii . pdf diakses pada tanggaJ 26 Februari 2014

Sinta Saraswati. 2005. Layanan Bimbingan Kelompok dalam Diklat Guru Pembimbing SMA Propinsi Jawa Tengah oleh LPMP Jawa Tengah.

Suharsimi Arikunto. 2007. Penilaian Laporan Penelitian Tindakan Kelas (PTK), Seminar Sehari dengan Tema Sertifikasi dan Penelitian Tindakan Kelas, Forum Kornunikasi Guru BK Kabupaten 
Purworejo.

Suwarjo dan Eva Imania Eliasa.2011.

Permainan (Games) dalam Bimbingan dan

Konseling. Yogyakarta: Paramita Publising .

Tadjri, Imam. 2012. Penelitian

Tindakan Bimbingan \& Konseling.

Semarang: Widya Karya. 